\title{
Transition Metal Coordination Polymers with Trans-1,4-Cyclohexanedicarboxylate: Acidity-Controlled Synthesis, Structures and Properties
}

\author{
Pavel A. Demakov ${ }^{1,2}$, Artem S. Bogomyakov ${ }^{2,3}$, Artem S. Urlukov ${ }^{1,2}$, Aleksandra Yu. Andreeva ${ }^{1}$, \\ Denis G. Samsonenko ${ }^{1,2}{ }^{-}$, Danil N. Dybtsev ${ }^{1,2}$ and Vladimir P. Fedin ${ }^{1,2, *}$ \\ 1 Nikolaev Institute of Inorganic Chemistry SB RAS, Novosibirsk 630090, Russia; \\ demakov@niic.nsc.ru (P.A.D.); a.urlukov@g.nsu.ru (A.S.U.); andreeva@niic.nsc.ru (A.Y.A.); \\ denis@niic.nsc.ru (D.G.S.); dan@niic.nsc.ru (D.N.D.) \\ 2 Department of Natural Sciences, Novosibirsk State University, Novosibirsk 630090, Russia; bus@tomo.nsc.ru \\ 3 International Tomography Center SB RAS, Novosibirsk 630090, Russia \\ * Correspondence: cluster@niic.nsc.ru
}

Received: 26 December 2019; Accepted: 17 January 2020; Published: 19 January 2020

\begin{abstract}
Five trans-1,4-cyclohexanedicarboxylate $\left(\mathrm{chdc}^{2-}\right)$ metal-organic frameworks of transition metals were synthesized in aqueous systems. A careful control of $\mathrm{pH}$, reaction temperature and solvent composition were shown to direct the crystallization of a particular compound. Isostructural $\left[\mathrm{Co}\left(\mathrm{H}_{2} \mathrm{O}\right)_{4}(\mathrm{chdc})\right]_{\mathrm{n}}(\mathbf{1})$ and $\left[\mathrm{Fe}\left(\mathrm{H}_{2} \mathrm{O}\right)_{4}(\mathrm{chdc})\right]_{\mathrm{n}}(2)$ consist of one-dimensional hydrogen-bonded chains. Compounds $\left[\mathrm{Cd}\left(\mathrm{H}_{2} \mathrm{O}\right)(\mathrm{chdc})\right]_{\mathrm{n}} \cdot 0.5 \mathrm{nCH}_{3} \mathrm{CN}(3),\left[\mathrm{Mn}_{4}\left(\mathrm{H}_{2} \mathrm{O}\right)_{3}(\mathrm{chdc})_{4}\right]_{\mathrm{n}}(4)$ and $\left[\mathrm{Mn}_{2}(\text { Hchdc })_{2}(\mathrm{chdc})\right]_{\mathrm{n}}$ (5) possess three-dimensional framework structures. The compounds 1, 4 and 5 were further characterized by magnetochemical analysis, which reveals paramagnetic nature of these compounds. A presence of antiferromagnetic exchange at low temperatures is observed for $\mathbf{5}$ while the antiferromagnetic coupling in 4 is rather strong, even at ambient conditions. The thermal decompositions of $\mathbf{1}, 4$ and 5 were investigated and the obtained metal oxide (cubic $\mathrm{Co}_{3} \mathrm{O}_{4}$ and $\mathrm{MnO}$ ) samples were analyzed by $\mathrm{X}$-ray diffraction and scanning electron microscopy.
\end{abstract}

Keywords: metal-organic frameworks; coordination polymers; aliphatic ligands; synthesis; magnetochemical study; thermolysis; metal oxides

\section{Introduction}

Metal-organic frameworks (MOFs) are one of the most fascinating family of solid-state materials because of their highly tunable compositions, structures and functional properties [1]. Lying on the crossing of fundamental inorganic/organic chemistry and development of novel materials, MOFs have become one of the most attractive research fields during the past two decades [2-4]. Typically, aromatic carboxylate ligands are used to construct porous coordination frameworks due to high rigidity of such linkers. For example, terephthalate $\left(\mathrm{bdc}^{2-}\right)$ linker is reported in more than 2500 examples of metal-organic coordination polymers (CSD May 2019). On the other hand, its aliphatic counterpart, that is trans-1,4-cyclohexanedicarboxylate $\left(\mathrm{chdc}^{2-}\right)$, is far less explored despite appropriate rigidity and availability. Among other reasons, a synthesis of such aliphatic-based MOFs is generally more challenging and requires a careful customization of reaction parameters, such as temperature, crystallization time, solvent composition, template role, coordination modulators, acidity/basicity of the reaction medium, etc. [5-8], which are often hard to rationalize. More efforts are required to prepare new aliphatic-based MOFs, however, the successful syntheses could lead to unusual crystal structures as a result of hydrophobic interactions between aliphatic moieties and their unique effect on the crystal packing [9-11]. An increased conformational lability of organic blocks provides ligand-driven structural 
transitions in the corresponding porous networks, including reversible breathing phenomena [12-16]. Also, a lower thermal stability of the aliphatic linkers allows for the introduction of defects into regular MOF structures [17], as well as synthesis of various metal oxide nanoparticles [18], and nanoporous carbon materials $[19,20]$, etc.

According to the literature, only one cobalt [21], two cadmium [22,23] and one mixed-valence Fe(II/III) [24] MOF with the single bridge ligand trans-1,4-cyclohexanedicarboxylate have been prepared before. Recently, we also reported the modulation of crystallization of chdc-based MOFs by urotropine in organic solvents [25]. Motivated by a lack of development of aliphatic-based MOFs, we investigated the water-based reaction systems of trans-1,4-cyclohexanedicarboxylic acid $\left(\mathrm{H}_{2} \mathrm{chdc}\right)$ and transition metal cations $\left(\mathrm{Co}^{2+}, \mathrm{Fe}^{2+}, \mathrm{Cd}^{2+}, \mathrm{Mn}^{2+}\right)$. The weak organic bases (1,4-diazabicyclo[2.2.2] octane, urotropine) were used to modulate and buffer the acidity of the reaction mixture for the optimal crystal growth conditions. Magnetic properties in the temperature range of 2-300 K were investigated. A controlled thermolysis of MOFs results in a formation of nanostructured metal oxides, the composition, structure and morphology of which were analyzed and discussed.

\section{Materials and Methods}

\subsection{Materials}

Trans-1,4-cyclohexanedicarboxylic acid $\left(\mathrm{H}_{2} \mathrm{chdc},>97.0 \%\right)$ and 1,4-diazabicyclo[2.2.2] (DABCO, $>98.0 \%$ ) were purchased from TCI (Tokyo, Japan). $\mathrm{Mn}\left(\mathrm{ClO}_{4}\right)_{2} \cdot 6 \mathrm{H}_{2} \mathrm{O}(>99.0 \%$ ) and urotropine (>99.0\%) were purchased from Sigma Aldrich (St. Louis, MO, USA). $\mathrm{HClO}_{4}$ 65\% water solution (reagent grade) and Fe powder (high-purity grade) were purchased from Reachem (Moscow, Russia). All reagents were used as purchased without further purification. Distilled water was used in all experiments.

\subsection{Characterization Techniques}

Infrared (IR) spectra in KBr pellets in the range $4000-400 \mathrm{~cm}^{-1}$ were recorded on a Bruker Scimitar FTS 2000 spectrometer (Billerica, MA, USA). Thermogravimetric (TG) analysis in the temperature range 30-600 ${ }^{\circ} \mathrm{C}$ was carried out using a Netzsch TG 209 F1 Iris instrument (Selb, Germany). The experiments were performed under He or Ar flow $\left(80 \mathrm{~cm}^{3} \mathrm{~min}^{-1}\right)$ at a $10 \mathrm{~K} \mathrm{~min}^{-1}$ heating rate. Elemental analysis was made on a EuroVector EA3000 analyzer (Pavia, Italy). Powder X-ray diffraction (PXRD) analysis was performed at room temperature on a Shimadzu XRD-7000 diffractometer $(\mathrm{Cu}-\mathrm{K} \alpha$ radiation, $\lambda=1.54178$ $\AA$, Kyoto, Japan). pH of the solutions was measured by Anion 4100 pH meter (Novosibirsk, Russia). SEM images were made on TM-3000 Scanning Electron Microscope (Osaka, Japan). Typical conditions for the measurements were the following: $20.0 \mathrm{kV}$ accelerating voltage, high vacuum pumping.

Investigation of magnetic properties of the compound 1 was performed on a Faraday balance (sensitivity $\sim 3 \cdot \times 10^{-7} \mathrm{~g}$ ). Measurements of the magnetic susceptibility were performed in the field of $9.7 \mathrm{kOe}$, the stabilization accuracy of the field strength was $2 \%$. During measurements, the samples were placed in an inert helium atmosphere at the pressure of 5 torr. The magnetic susceptibility of the polycrystalline samples 4 and 5 was measured with a Quantum Design MPMSXL SQUID magnetometer (San Diego, CA, USA) in the temperature range 2-300 K with magnetic field of up to $5 \mathrm{kOe}$. None of the complexes exhibited any field dependence of molar magnetization at low temperatures. Diamagnetic corrections were made using the Pascal constants. The effective magnetic moment was calculated as $\mu_{\mathrm{eff}}(\mathrm{T})=\left[\left(3 \mathrm{k} / \mathrm{N}_{\mathrm{A}} \mu_{\mathrm{B}}^{2}\right) \chi T\right]^{1 / 2} \approx(8 \chi T)^{1 / 2}$.

\subsection{Synthesis}

\subsubsection{Synthesis of $\left[\mathrm{Co}\left(\mathrm{H}_{2} \mathrm{O}\right)_{4}(\text { chdc })\right]_{n}(\mathbf{1})$}

$100 \mathrm{mg}(0.34 \mathrm{mmol})$ of $\mathrm{Co}\left(\mathrm{NO}_{3}\right)_{2} \cdot 6 \mathrm{H}_{2} \mathrm{O}, 56 \mathrm{mg}(0.33 \mathrm{mmol})$ of $\mathrm{H}_{2}$ chdc and $24 \mathrm{mg}(0.17 \mathrm{mmol})$ of urotropine were dissolved in $8.00 \mathrm{~mL}$ of $\mathrm{H}_{2} \mathrm{O}$ in a $10 \mathrm{~mL}$ glass flask and heated at $80{ }^{\circ} \mathrm{C}$ for $18 \mathrm{~h}$. After 
the cooling at the room temperature, the crimson crystals were filtered off, washed with water and dried in air. Yield: $66 \mathrm{mg}(67 \%)$. IR $\left(\mathrm{KBr}, \mathrm{cm}^{-1}\right): 3433$ (br. m, $\left.v_{\mathrm{O}-\mathrm{H}}\right), 3276(\mathrm{~m}), 2957\left(\mathrm{~m}, v_{\mathrm{C}-\mathrm{H}}\right), 2947(\mathrm{~m}$, $\left.v_{\mathrm{C}-\mathrm{H}}\right), 2933\left(\mathrm{~m}, v_{\mathrm{C}-\mathrm{H}}\right), 2865\left(\mathrm{~m}, v_{\mathrm{C}-\mathrm{H}}\right), 2241(\mathrm{w}), 1552\left(\mathrm{~s}, v_{\mathrm{COOas}}\right), 1406\left(\mathrm{~s}, v_{\mathrm{COOs}}\right), 1363(\mathrm{~m}), 1328(\mathrm{~m})$, $1292(\mathrm{~m}), 1227(\mathrm{w}), 1213(\mathrm{w}), 1090(\mathrm{w}), 1048(\mathrm{w}), 974(\mathrm{~m}), 916(\mathrm{~m}), 888(\mathrm{w}), 778(\mathrm{~s}), 713(\mathrm{~m}), 544(\mathrm{~m}), 500$ (m). Elemental analysis data calculated for $\left[\mathrm{Co}\left(\mathrm{H}_{2} \mathrm{O}\right)_{4}(\mathrm{chdc})\right]: \mathrm{C} 31.9 \%, \mathrm{H} 6.0 \%$. Found: $\mathrm{C} 31.3 \%, \mathrm{H}$ $5.8 \%$.

\subsubsection{Synthesis of $\left[\mathrm{Fe}\left(\mathrm{H}_{2} \mathrm{O}\right)_{4}(\mathrm{chdc})\right]_{\mathrm{n}}(2)$}

$10 \mathrm{mg}(0.18 \mathrm{mmol})$ of $\mathrm{Fe}$ powder were dispersed in $1.00 \mathrm{~mL}$ of $\mathrm{H}_{2} \mathrm{O}$ and $0.035 \mathrm{~mL}$ of $65 \%$ $(0.56 \mathrm{mmol}) \mathrm{HClO}_{4}$ were added. After dissolution of iron, $28 \mathrm{mg}(0.16 \mathrm{mmol})$ of $\mathrm{H}_{2} \mathrm{chdc}$ and $24 \mathrm{mg}$ $(0.17 \mathrm{mmol})$ of urotropine were added to the mixture in the glass ampoule. Then the ampoule was soldered, then sonicated for $10 \mathrm{~min}$ and heated at $80^{\circ} \mathrm{C}$ for $18 \mathrm{~h}$. After cooling at room temperature, the ampoule was opened and the colorless single crystals were selected for single crystal X-ray diffraction (SCXRD) analysis.

\subsubsection{Synthesis of $\left[\mathrm{Cd}\left(\mathrm{H}_{2} \mathrm{O}\right)(\mathrm{chdc})\right]_{\mathrm{n}} \cdot 0.5 \mathrm{nCH}_{3} \mathrm{CN}$ (3)}

$350 \mathrm{mg}$ of $\mathrm{Cd}\left(\mathrm{NO}_{3}\right)_{2} \cdot 4 \mathrm{H}_{2} \mathrm{O}(1.13 \mathrm{mmol})$ were dissolved in $15.00 \mathrm{~mL}$ of acetonitrile. $250 \mathrm{mg}$ (1.45 mmol) of $\mathrm{H}_{2} \mathrm{chdc}$ and $150 \mathrm{mg}(1.34 \mathrm{mmol})$ of DABCO were dissolved in $15.00 \mathrm{~mL}$ of water. Then, the obtained solutions were mixed in a $50 \mathrm{~mL}$ Teflon vessel and heated at $100{ }^{\circ} \mathrm{C}$ for $24 \mathrm{~h}$. After the cooling at the room temperature, the white precipitate was filtered off, washed with acetonitrile and dried in air. Yield: $192 \mathrm{mg}(52 \%)$. IR $\left(\mathrm{KBr}, \mathrm{cm}^{-1}\right): 3534\left(\mathrm{~m}, v_{\mathrm{O}-\mathrm{H}}\right), 3389$ (br. m, $\left.v_{\mathrm{O}-\mathrm{H}}\right), 2936\left(\mathrm{~m}, v_{\mathrm{C}-\mathrm{H}}\right)$, $2857\left(\mathrm{~m}, v_{\mathrm{C}-\mathrm{H}}\right), 2257(\mathrm{w}), 2051(\mathrm{w}), 1643(\mathrm{~m}), 1579\left(\mathrm{~s}, v_{\mathrm{COO} a s}\right), 1450(\mathrm{~m}), 1422$ (s, $\left.v_{\mathrm{COOs}}\right), 1386(\mathrm{~m})$, $1359(\mathrm{~m}), 1328(\mathrm{~m}), 1288(\mathrm{~m}), 1270(\mathrm{~m}), 1212(\mathrm{~m}), 1043(\mathrm{w}), 975(\mathrm{w}), 928(\mathrm{~m}), 902(\mathrm{w}), 887(\mathrm{w}), 809(\mathrm{w})$, $790(\mathrm{~m}), 758(\mathrm{w}), 738(\mathrm{w}), 691(\mathrm{w}), 675(\mathrm{w}), 537(\mathrm{w}), 470(\mathrm{~m})$. Elemental analysis data calculated for $\left[\mathrm{Cd}\left(\mathrm{H}_{2} \mathrm{O}\right)(\mathrm{chdc})\right] \cdot 0.5 \mathrm{CH}_{3} \mathrm{CN}$ : C 33.4\%, H 4.2\%, N 2.2\%. Found: C 33.3\%, H 4.0\%, N 2.2\%.

\subsubsection{Synthesis of $\left[\mathrm{Mn}_{4}\left(\mathrm{H}_{2} \mathrm{O}\right)_{3}(\mathrm{chdc})_{4}\right]_{\mathrm{n}}(4)$}

$300 \mathrm{mg}(0.83 \mathrm{mmol})$ of $\mathrm{Mn}\left(\mathrm{ClO}_{4}\right)_{2} \cdot 6 \mathrm{H}_{2} \mathrm{O}, 120 \mathrm{mg}(0.70 \mathrm{mmol})$ of $\mathrm{H}_{2}$ chdc and $120 \mathrm{mg}(0.86 \mathrm{mmol})$ of urotropine were dispersed in $5.00 \mathrm{~mL}$ of $\mathrm{H}_{2} \mathrm{O}$ in a $10 \mathrm{~mL}$ glass flask and sonicated for $5 \mathrm{~min}$. Then the flask was heated at $80^{\circ} \mathrm{C}$ for $18 \mathrm{~h}$. After the cooling at the room temperature, the white precipitate was filtered off, washed several times with water and dried in air. Yield: $85 \mathrm{mg}(51 \%)$. IR $\left(\mathrm{KBr}, \mathrm{cm}^{-1}\right)$ : $3615\left(\mathrm{w}, v_{\mathrm{O}-\mathrm{H}}\right), 3572\left(\mathrm{w}, v_{\mathrm{O}-\mathrm{H}}\right), 3348$ (br. m, $\left.v_{\mathrm{O}-\mathrm{H}}\right), 2932\left(\mathrm{~m}, v_{\mathrm{C}-\mathrm{H}}\right), 2856\left(\mathrm{~m}, \mathrm{v}_{\mathrm{C}-\mathrm{H}}\right), 1623$ (m), 1562 (s, $\left.v_{\text {COOas }}\right), 1448(\mathrm{~m}), 1417\left(\mathrm{~s}, v_{\text {COOs }}\right), 1388(\mathrm{~m}), 1358(\mathrm{~m}), 1327(\mathrm{~m}), 1281(\mathrm{~m}), 1210(\mathrm{~m}), 1144(\mathrm{~m}), 1109(\mathrm{~m})$, $1049(\mathrm{w}), 977(\mathrm{w}), 927(\mathrm{~m}), 901(\mathrm{~m}), 886(\mathrm{w}), 812(\mathrm{w}), 778(\mathrm{~m}), 745(\mathrm{~m}), 709(\mathrm{~m}), 685(\mathrm{~m}), 590(\mathrm{w}), 555(\mathrm{~m})$, $532(\mathrm{~m}), 479(\mathrm{~s}), 397(\mathrm{~m})$. Elemental analysis data calculated for $\left[\mathrm{Mn}_{4}\left(\mathrm{H}_{2} \mathrm{O}\right)_{3}(\mathrm{chdc})_{4}\right]: \mathrm{C} 40.3 \%, \mathrm{H} 4.8 \%$. Found: C $40.6 \%$, H 5.0\%.

\subsubsection{Synthesis of $\left[\mathrm{Mn}_{2}(\mathrm{Hchdc})_{2}(\mathrm{chdc})\right]_{\mathrm{n}}(5)$}

$300 \mathrm{mg}(0.83 \mathrm{mmol})$ of $\mathrm{Mn}\left(\mathrm{ClO}_{4}\right)_{2} \cdot 6 \mathrm{H}_{2} \mathrm{O}, 280 \mathrm{mg}(1.63 \mathrm{mmol})$ of $\mathrm{H}_{2}$ chdc and $120 \mathrm{mg}(0.86 \mathrm{mmol})$ of urotropine were dispersed in $5.00 \mathrm{~mL}$ of $\mathrm{H}_{2} \mathrm{O}$ and $0.025 \mathrm{~mL}$ of $65 \%(0.40 \mathrm{mmol}) \mathrm{HClO}_{4}$ was added. Then the mixture was sonicated for $5 \mathrm{~min}$ and heated at $120^{\circ} \mathrm{C}$ for $30 \mathrm{~min}$ in a screwed-cap glass vial to allow a partial evaporation of the reaction solution (ca. to $4 \mathrm{~mL}$ total volume). The crystallized white precipitate was hot-filtered and washed quickly with $\mathrm{H}_{2} \mathrm{O}$ to avoid the formation of the compound 4 impurity. After washing, the product was dried in air. Yield: $87 \mathrm{mg}(34 \%)$. IR (KBr, cm $\left.{ }^{-1}\right): 3448$ (br. w, $\left.v_{\mathrm{O}-\mathrm{H}}\right), 2928\left(\mathrm{~s}, v_{\mathrm{C}-\mathrm{H}}\right), 2856\left(\mathrm{~s}, v_{\mathrm{C}-\mathrm{H}}\right), 2659(\mathrm{w}), 2550(\mathrm{w}), 1672(\mathrm{~s}), 1586\left(\mathrm{~s}, v_{\mathrm{COO}}\right), 1540(\mathrm{~m}), 1439(\mathrm{~m})$, $1409\left(\mathrm{~s}, v_{\mathrm{COO}}\right), 1383(\mathrm{~m}), 1362(\mathrm{~m}), 1330(\mathrm{~m}), 1273(\mathrm{~m}), 1246(\mathrm{~m}), 1214(\mathrm{~m}), 1134(\mathrm{w}), 1110(\mathrm{~m}), 1039(\mathrm{w})$, $1024(\mathrm{w}), 977(\mathrm{w}), 953(\mathrm{w}), 916(\mathrm{~m}), 882(\mathrm{w}), 801(\mathrm{w}), 770(\mathrm{w}), 741(\mathrm{~m}), 722(\mathrm{w}), 711(\mathrm{w}), 682(\mathrm{w}), 543(\mathrm{w})$, $529(\mathrm{~m}), 472(\mathrm{~m}), 404(\mathrm{~m})$. Elemental analysis data calculated for $\left[\mathrm{Mn}_{2}(\mathrm{Hchdc})_{2}(\mathrm{chdc})\right]: \mathrm{C} 46.3 \%, \mathrm{H}$ $5.1 \%$. Found: C $46.4 \%$, H 5.2\%. 


\subsubsection{Synthesis of Oxides}

50-100 $\mathrm{mg}$ of 1,4 or 5 were placed in an open porcelain crucible and heated with $4{ }^{\circ} \mathrm{C} \cdot \mathrm{min}^{-1}$ rate up to $600^{\circ} \mathrm{C}$ in an oven, kept at $600{ }^{\circ} \mathrm{C}$ for $2 \mathrm{~h}$ and cooled to the room temperature with $4{ }^{\circ} \mathrm{C} \cdot \mathrm{min}^{-1}$ cooling rate.

\subsection{X-ray Crystallography}

Diffraction data for single-crystals of $\mathbf{1 - 5}$ were obtained at $130 \mathrm{~K}$ on an automated Agilent Xcalibur diffractometer (Santa Clara, CA, USA) equipped with an area AtlasS2 detector (graphite monochromator, $\lambda(\mathrm{MoK} \alpha)=0.71073 \AA$, $\omega$-scans). Integration, absorption correction, and determination of unit cell parameters were performed using the CrysAlisPro 1.171.38.46 program package [26]. The structures were solved by dual space algorithm (SHELXT [27]) and refined by the full-matrix least squares technique (SHELXL [28]) in the anisotropic approximation (except hydrogen atoms). Positions of hydrogen atoms of organic ligands were calculated geometrically and refined in the riding model. A crystal structure of 5 is solved in two alternatives: orthorhombic $F d d 2$ (5o) and monoclinic $P 2_{1}$ (5m). The crystallographic data and details of the structure refinements are summarized in Table A1. Cambridge Crystallographic Data Center (CCDC) numbers 1973662-1973668 contain the supplementary crystallographic data for this paper. These data can be obtained free of charge from The Cambridge Crystallographic Data Center at https://www.ccdc.cam.ac.uk/structures/.

\section{Results and Discussion}

\subsection{Synthesis}

Compound $\left[\mathrm{Co}\left(\mathrm{H}_{2} \mathrm{O}\right)_{4}(\mathrm{chdc})\right]_{\mathrm{n}}(\mathbf{1})$ was obtained with $67 \%$ yield by heating $\left(80^{\circ} \mathrm{C}\right)$ of an aqueous solution of stoichiometric amount of cobalt (II) nitrate and trans-1,4-cyclohexanedicarboxylic acid in the presence of urotropine. The phase purity of 1 was confirmed by PXRD (Figure S1). The crystallization takes place in a mildly acidic conditions $\left(\mathrm{pH}_{\text {start }}=4.5, \mathrm{pH}_{\text {final }}=5.0\right)$. In comparison, other cobalt-chdc compounds $\left[\mathrm{Co}_{5}(\mathrm{OH})_{8}(\mathrm{chdc})\right]_{n} \cdot 4 \mathrm{nH}_{2} \mathrm{O}$ reported earlier by Kurmoo et al. [21], was synthesized in hydrothermal conditions $\left(170^{\circ} \mathrm{C}\right)$ using an excess of $\mathrm{NaOH}$ to create strongly alkaline medium, which apparently facilitates a formation of hydroxyl-rich polynuclear $\left\{\mathrm{Co}_{5}(\mathrm{OH})_{8}\right\}_{\mathrm{n}}{ }^{2+}$ building blocks. In moderately acidic synthetic conditions used herein, only mononuclear aqua-complexes were obtained. It should be noted that carrying out the synthesis of $\mathbf{1}$ without urotropine results in a recrystallization of $\mathrm{H}_{2}$ chdc (See Appendix A, Figures A1 and A2) after the cooling. On the contrary, an elevation of the basicity of the reaction system by either increasing the amount of urotropine (two times) or by a replacement of urotropine to the stronger base $(\mathrm{NaOH})$ only lead to the formation of the unknown white powder. Details of the optimized synthetic methods for all compounds are summarized in Table 1.

Table 1. Synthetic details for $\mathbf{1}-\mathbf{5}$.

\begin{tabular}{|c|c|c|c|c|c|c|c|}
\hline $\begin{array}{l}\text { Compound } \\
\text { Number }\end{array}$ & Compound Formula & $\begin{array}{c}\mathrm{M}^{2+}: \mathrm{H}_{2} \text { chdc: Base } \\
\text { (Molar Ratio) }\end{array}$ & $\mathrm{T},{ }^{\circ} \mathrm{C}$ & $\mathrm{pH}_{\text {start }}$ & $\mathrm{p} \mathrm{H}_{\text {final }}$ & $\begin{array}{l}\text { Product at } \\
\text { Higher pH }\end{array}$ & $\begin{array}{l}\text { Product at } \\
\text { Lower pH }\end{array}$ \\
\hline 1 & {$\left[\mathrm{Co}\left(\mathrm{H}_{2} \mathrm{O}\right)_{4}(\mathrm{chdc})\right]_{\mathrm{n}}$} & 1: $1: 0.5$ & 80 & 4.5 & 5.0 & unknown & $\mathrm{H}_{2}$ chdc \\
\hline 2 & {$\left[\mathrm{Fe}\left(\mathrm{H}_{2} \mathrm{O}\right)_{4}(\mathrm{chdc})\right]_{\mathrm{n}}$} & 1: $1: 0.75$ & 80 & - & - & unknown & $\mathrm{H}_{2}$ chdc \\
\hline 3 & {$\left[\mathrm{Cd}\left(\mathrm{H}_{2} \mathrm{O}\right)(\mathrm{chdc})\right]_{\mathrm{n}} 0.5 \mathrm{nCH}_{3} \mathrm{CN}$} & 1: $1.3: 1.2$ & 100 & 4.8 & 4.5 & {$\left[\mathrm{Cd}\left(\mathrm{H}_{2} \mathrm{O}\right)_{2}(\mathrm{chdc})\right]_{\mathrm{n}}$} & $\mathrm{H}_{2}$ chdc \\
\hline 4 & {$\left[\mathrm{Mn}_{4}\left(\mathrm{H}_{2} \mathrm{O}\right)_{3}(\mathrm{chdc})_{4}\right]_{\mathrm{n}}$} & 1: 0.8: 1 & 80 & 4.9 & 5.2 & - & $\mathrm{H}_{2}$ chdc \\
\hline 5 & {$\left[\mathrm{Mn}_{2}(\text { Hchdc })_{2}(\mathrm{chdc})\right]_{\mathrm{n}}$} & 1: $2: 1$ & 80 & 4.6 & 4.9 & - & $\mathrm{H}_{2}$ chdc \\
\hline
\end{tabular}

Compound $\left[\mathrm{Fe}\left(\mathrm{H}_{2} \mathrm{O}\right)_{4}(\mathrm{chdc})\right]_{\mathrm{n}}(2)$ was obtained by heating $\left(80^{\circ} \mathrm{C}\right)$ of aqueous solution of $\mathrm{H}_{2}$ chdc, urotropine and $\mathrm{Fe}\left(\mathrm{ClO}_{4}\right)_{2}$, which was synthesized in situ by the dissolution of $\mathrm{Fe}$ in the solution of perchloric acid. Despite our attempts to avoid the oxidation of iron(II), the crystalline precipitate of 2 was always contaminated by hydrated ferric(III) oxide; therefore, the chemical composition and structure were established by a single-crystal X-ray analysis only. Urotropine is not included 
in the final coordination polymer, but is a necessary component of the reaction mixture, apparently as a $\mathrm{pH}$ modulator for the proper crystallization process. Remarkably, $\mathbf{2}$ is the first structurally characterized example of iron(II) 1,4-cychohexanedicarboxyalte reported in the literature, besides of one mixed-valence $\mathrm{Fe}(\mathrm{II} / \mathrm{III})$ compound [Fe $\left.2 \mathrm{O}(\mathrm{chdc})_{1.5}\right]_{\mathrm{n}}$ [24]. 2 is isostructural to $\mathbf{1}$ and to $\left[\mathrm{Ni}\left(\mathrm{H}_{2} \mathrm{O}\right)_{4}(\mathrm{chdc})\right]$, which was reported by Kurmoo et al. [29] and Chen et al. [7].

Compound $\left[\mathrm{Cd}\left(\mathrm{H}_{2} \mathrm{O}\right)(\mathrm{chdc})\right]_{\mathrm{n}} \cdot 0.5 \mathrm{nCH}_{3} \mathrm{CN}$ (3) was synthesized in the solvothermal conditions by heating $\left(100{ }^{\circ} \mathrm{C}\right)$ of the cadmium(II) nitrate, $\mathrm{H}_{2}$ chdc and DABCO in the mixture of water and acetonitrile. The phase purity of 3 was confirmed by PXRD (Figure S2). The starting $\mathrm{pH}$ of the solution $\left(\mathrm{pH}_{\text {start }}=4.8\right)$ is only slightly changed during the reaction $\left(\mathrm{pH}_{\text {final }}=4.5\right)$. The synthesis of one-dimensional compound $\left[\mathrm{Cd}\left(\mathrm{H}_{2} \mathrm{O}\right)_{2}(\mathrm{chdc})\right]_{n}$, reported by Thirumurugan et al. [23], was carried out in water from cadmium acetate and $\mathrm{H}_{2}$ chdc with piperidine as the acidity modulator, while $\left[\mathrm{Cd}_{2}(\mathrm{DMF})(\mathrm{chdc})_{2}\right]_{\mathrm{n}}$, reported by Yoon and co-workers [22], was obtained from the organic medium (N,N-dimethylformamide). In our case, both water/acetonitrile mixture and DABCO appeared to be necessary for synthesis 3 , since the reaction in pure solvents did not result in any MOF precipitation except for recrystallization of $\mathrm{H}_{2}$ chdc. Using one equivalent of $\mathrm{NaOH}$ instead of DABCO led to the formation of single crystals of the known compound $\left[\mathrm{Cd}\left(\mathrm{H}_{2} \mathrm{O}\right)_{2}(\mathrm{chdc})\right]$. Oddly enough, no precipitate was formed if replacing 1,4-diazabicyclo[2.2.2] octane $\left(\mathrm{DABCO}, \mathrm{pK} \mathrm{b}_{\mathrm{b}}=5.2\right)$ [30] to urotropine $\left(\mathrm{pK}_{\mathrm{b}}=\right.$ 9.5); therefore, in addition to being a very specific $\mathrm{pH}$ modulator, $\mathrm{DABCO}$ molecules probably act as an intermediate template facilitating the crystallization of 3 . The starting $\mathrm{pH}\left(\mathrm{pH}_{\text {start }}=4.8\right)$ is quite similar to the reported $\mathrm{pH}=5 \ldots 6$ in the synthesis of $\left[\mathrm{Cd}\left(\mathrm{H}_{2} \mathrm{O}\right)_{2}(\mathrm{chdc})\right]_{\mathrm{n}}[23]$, but the role of DABCO in our case is likely to fix $\mathrm{pH}$ at certain values to complement the templation effect.

New Mn-based MOFs $\left[\mathrm{Mn}_{4}\left(\mathrm{H}_{2} \mathrm{O}\right)_{3}(\mathrm{chdc})_{4}\right]_{\mathrm{n}}(4)$ and $\left[\mathrm{Mn}_{2}(\mathrm{Hchdc})_{2}(\mathrm{chdc})\right]_{\mathrm{n}}(5)$ were obtained in aqueous medium from the manganese(II) perchlorate, $\mathrm{H}_{2}$ chdc and urotropine. Due to the similar chemical compositions, the simultaneous precipitation of these two compounds is hard to avoid. After optimization of the reaction conditions, the pure phase of 4 was obtained at lower acidity $\left(\mathrm{pH}_{\text {start }}=4.9\right.$; $\left.\mathrm{pH}_{\text {final }}=5.2\right)$ while the compound 5 was isolated at higher acidity of the reaction solution $\left(\mathrm{pH}_{\text {start }}\right.$ $=4.6 ; \mathrm{pH}_{\text {final }}=4.9$ ) due to (i) greater molar ratio of chdc: $\mathrm{Mn}$ and (ii) additional presence of strong $\mathrm{HClO}_{4}$ acid. Such conditions are consistent with a more "acidic" nature of 5 , which contains a partially protonated Hchdc ${ }^{-}$moieties, compared with 4, where only fully deprotonated chdc $^{2-}$ ligands are present. Importantly, the concentration of the urotropine in the synthesis of both 4 and 5 should not be lowered to avoid the formation of $\mathrm{H}_{2}$ chdc crystals. The phase purity of the obtained 4 and 5 samples was confirmed by PXRD (Figures S3 and S4).

\subsection{Structure Descriptions and Infrared Spectroscopy}

An asymmetric unit of $\left[\mathrm{Co}\left(\mathrm{H}_{2} \mathrm{O}\right)_{4}(\mathrm{chdc})\right]_{n}(\mathbf{1})$ contains one $\mathrm{Co}$ atom, which has an octahedral coordination environment of four aqua ligands and two $\mathrm{O}$ atoms of two COO-groups, which are situated in trans positions (Figure 1). $\mathrm{Co}-\mathrm{OH}_{2}$ distances are 2.0947(9) $\AA$ and 2.1168(10) $\AA$, and Co-OCO distance is 2.0993(9) $\AA$. The metal centers are bound by bidentate (e,e)-1,4-chdc ligands to form polymeric chains, which are packed into a dense crystal structure. It seems that both hydrogen bonding (interchain $\mathrm{O}_{\mathrm{COO}}-\mathrm{O}_{\text {aqua }}$ distances are $2.762 \AA$ for $\mathrm{O}(1) \cdots \mathrm{O}(12), 2.868 \AA$ for $\mathrm{O}(1) \cdots \mathrm{O}(11)$, and $2.889 \AA$ for $\mathrm{O}(2) \cdots \mathrm{O}(11))$ and hydrophobic interactions between cyclohexane rings play an important role in the formation of the dense phase. The smallest interlayer $\mathrm{H}_{\mathrm{CH}} \ldots \mathrm{H}_{\mathrm{CH}}$ distance is calculated to be $2.320 \AA$, which indicates a close linker-to-linker packing in 1. There is also an intramolecular hydrogen bond between aqua ligand and $\mathrm{O}$ atom of the COO-group $(\mathrm{O}(2) \cdots \mathrm{O}(12)$ distance is $2.652 \AA) .1$ is isostructural to $\left[\mathrm{Ni}\left(\mathrm{H}_{2} \mathrm{O}\right)_{4}(\mathrm{chdc})\right]_{\mathrm{n}}[7,29]$. The synthesis of $\left[\mathrm{Co}\left(\mu-\mathrm{H}_{2} \mathrm{O}\right)\left(\mathrm{H}_{2} \mathrm{O}\right)_{2} \text { (cis-chdc) }\right]_{n}$ containing a cis-isomer of 1,4-cyclohexanedicarboxylate ligand is also reported [31]. 


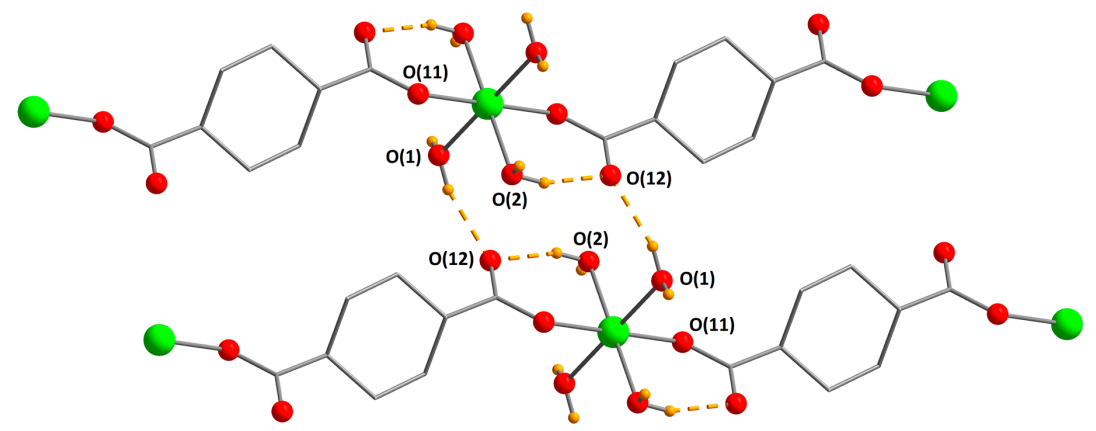

Figure 1. Packing of polymeric chains in $\mathbf{1}$ (CCDC 1973662). Metal atoms are green, $\mathrm{O}$ atoms are red, $\mathrm{H}$ atoms of aqua-ligands are orange. Hydrogen bonds are shown with dashed lines. $\mathrm{H}$ atoms of $\mathrm{chdc}^{2-}$ ligands are omitted.

Compound $\left[\mathrm{Fe}\left(\mathrm{H}_{2} \mathrm{O}\right)_{4}(\mathrm{chdc})\right]_{\mathrm{n}}$ (2) is isostructural to 1. $\mathrm{Fe}-\mathrm{OH}_{2}$ distances are 2.1292(12) $\AA$ and 2.1524(12) $\AA$, and $\mathrm{Fe}-\mathrm{OCO}$ distance is 2.1076(11) $\AA$. Interchain $\mathrm{O}_{\mathrm{COO}} \cdots \mathrm{O}_{\text {aqua }}$ distances are 2.753, 2.887, and $2.902 \AA$. The intramolecular $\mathrm{O}_{\mathrm{COO}} \cdots \mathrm{O}_{\text {aqua }}$ distance is $2.665 \AA$. Compound 2 is the first example of iron(II) cyclohexanedicarboxylate reported in the literature.

The asymmetric unit of the structure $\left[\mathrm{Cd}\left(\mathrm{H}_{2} \mathrm{O}\right)(\mathrm{chdc})\right]_{\mathrm{n}} \cdot 0.5 \mathrm{nCH}_{3} \mathrm{CN}$ (3) contains two $\mathrm{Cd}$ atoms, two trans-1,4-cyclohexanedicarboxylate ligands and two molecules of coordinated water. $\mathrm{Cd}(1)$ has a distorted octahedral coordination environment of five carboxylate $\mathrm{O}$ atoms and one aqua ligand. $\mathrm{Cd}(2)$ has less distorted octahedral coordination environment, which also consists of five carboxylate $\mathrm{O}$ atoms and one aqua ligand. $\mathrm{Cd}-\mathrm{O}$ distances are in range of 2.2224(16)-2.3860(17) $\AA$. $\mathrm{Cd}(1)$ and $\mathrm{Cd}(2)$ are interconnected via three bridging COO-groups to form a binuclear unit $\left\{\mathrm{Cd}_{2}\left(\mu-\mathrm{RCOO}-\kappa^{1}, \kappa^{1}\right)_{2}\left(\mu-\mathrm{RCOO}-\kappa^{1}\right)\right\}$. The binuclear units are interconnected to form waved polymeric chains parallel to the $\mathrm{c}$ axis (Figure 2a). The chains are interconnected by (e,e)-1,4-cyclohexanedicarboxylate ligands in six directions to form a 3D porous network (Figure 2b). There are isolated cages in structure 3 (two cages per unit cell). The void volume in 3 is $14 \%$ (PLATON [32]) and the voids are occupied by the guest $\mathrm{CH}_{3} \mathrm{CN}$ molecules (Figure S5).

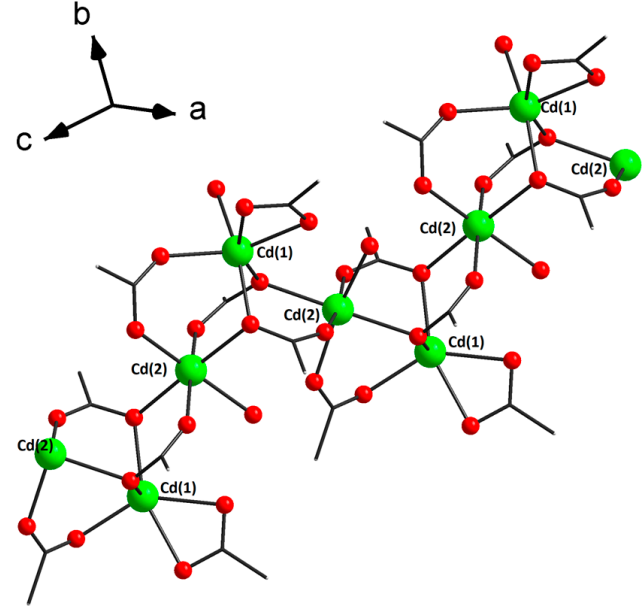

(a)

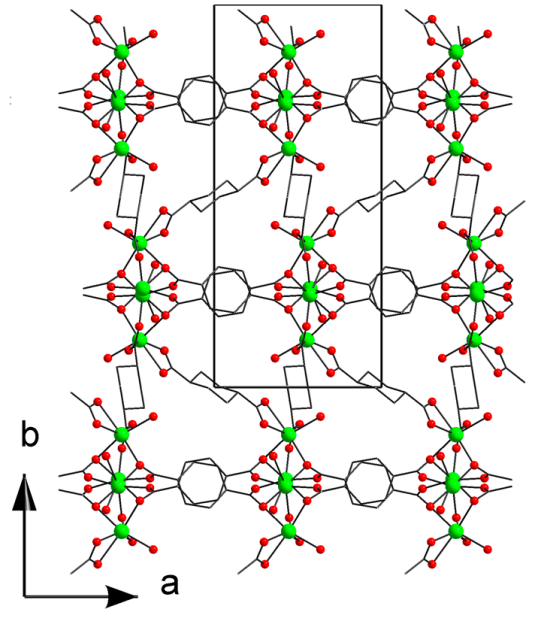

(b)

Figure 2. Fragment of polymeric chain (a) and 3D metal-organic framework (b) in 3 (CCDC 1973664). Hydrogen atoms and guest $\mathrm{CH}_{3} \mathrm{CN}$ molecules are omitted for clarity.

The asymmetric unit of $\left[\mathrm{Mn}_{4}\left(\mathrm{H}_{2} \mathrm{O}\right)_{3}(\mathrm{chdc})_{4}\right]_{\mathrm{n}}$ (4) contains four $\mathrm{Mn}$ atoms, four trans-1,4-cyclohexanedicarboxylate ligands and three molecules of coordinated water. $\mathrm{Mn}(1)$ has a distorted octahedral coordination environment containing six $\mathrm{O}$ atoms of five $\mathrm{COO}$-groups. 
$\operatorname{Mn}(2)$ and $M n(3)$ have less distorted octahedral coordination environment, which contains four $\mathrm{O}$ atoms of four COO-groups, one bridging and one terminal $\mathrm{H}_{2} \mathrm{O}$ molecule. $\mathrm{Mn}(4)$ has a slightly distorted square-pyramidal coordination environment containing five $\mathrm{O}$ atoms of five COO-groups. For octahedral Mn centers, the Mn-O distances are in the range of 2.0884(14)-2.3142(15) $\AA$ for

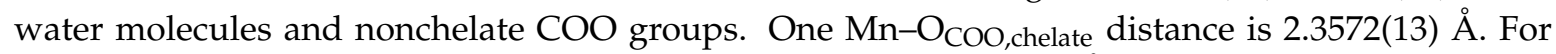
square-pyramidal Mn(4) center, Mn-O distances are 1.993(6)-2.219(7) $\AA$ and there is a long Mn(4)...O contact of $2.8047 \AA$. Mn atoms are interconnected via bridging carboxylate groups to form a decanuclear ring incorporating an endo-chdc ${ }^{2-}$ ligand (Figure 3a). Translating along the $a$ and $b$ axis, the decanuclear rings tile (004) plane to form polymeric layer with hexagonal topology (Figure 3b). Such a structure is unique for metal-organic frameworks, although there are reported examples of manganese or iron MOFs, which are constructed of endotemplated "honeycombs" with a different size or metal rings $[10,11,33,34]$. The layers alternate along the $c$ axis, interconnecting by bridging chdc $^{2-}$ ligands to form 3D metal-organic framework (see also Figures S6 and S7).

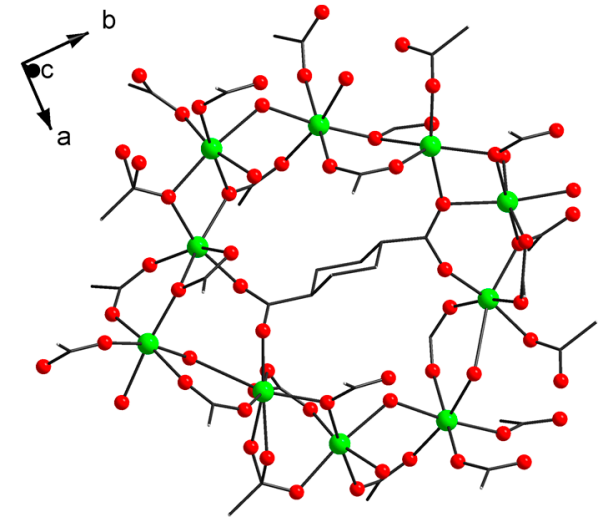

(a)

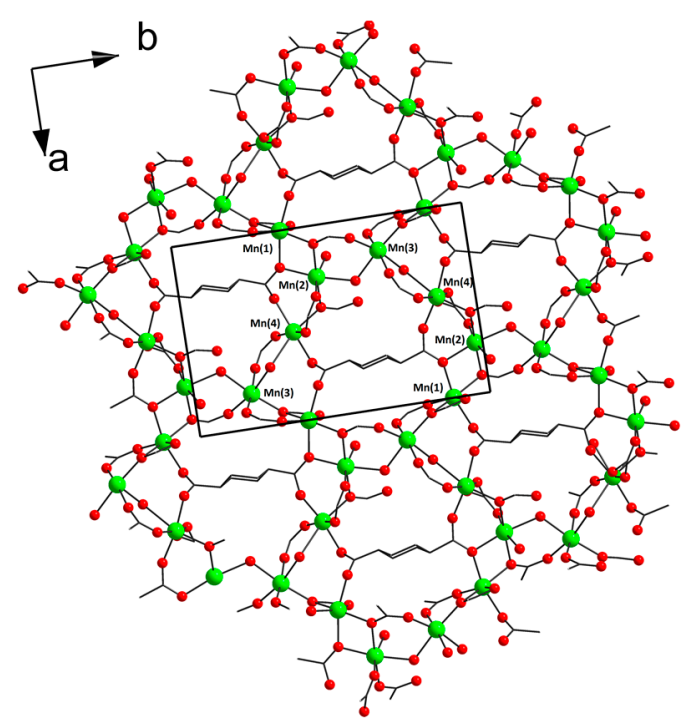

(b)

Figure 3. Decanuclear Mn(II) wheel with endo-chdc ${ }^{2-}$ ligand in 4 (CCDC 1973665) (a). Framework structure of 4 along the $c$ axis (b).

The crystal structure of the compound $\left[\mathrm{Mn}_{2}(\mathrm{Hchdc})_{2}(\mathrm{chdc})\right]_{\mathrm{n}}(5)$ could be solved in two alternatives: orthorhombic $F d d 2$ (5o) and monoclinic $P 2_{1}(\mathbf{5 m})$. Higher symmetry variant $5 \mathbf{o}$ has less independent atoms, and demonstrates lower $R_{1}$ value. However, in the structure $\mathbf{5 0}$, the chdc ${ }^{2-}$ ligand is disordered over two orientations around a two-fold rotary axis, whereas lower symmetry variant $5 \mathrm{~m}$ demonstrates no disordering in the structure, but is characterized by a higher $R_{1}$ value. Since the topology of framework $\mathbf{5}$ is the same in both cases, a further description of the crystal structure is given for the higher symmetry variant $\mathbf{5 o}$.

The asymmetric unit of $\mathbf{5}$ contains one $\mathrm{Mn}$ (II) cation, which has an octahedral coordination environment consisting of six $\mathrm{O}$ atoms of six COO-groups (Figure 4a). $\mathrm{Mn}-\mathrm{O}$ distances are in range 2.083(8)-2.211(3) $\AA$ for oxygen atoms of bridging COO groups and 2.325(4) $\AA$ for oxygen atom of monocoordinated carboxylate. Mn atoms are bridged through $\mathrm{COO}$-groups to form polymeric chain running along the $\mathrm{c}$ axis. The chains are interconnected by (e,e)-1,4-cyclohexanedicarboxylate ligands to form a 3D metal-organic framework (Figure 4b). One of the 1,4-cyclohexanedicarboxylates is monoprotonated. The structure is densely packed and has no free solvent accessible volume. 


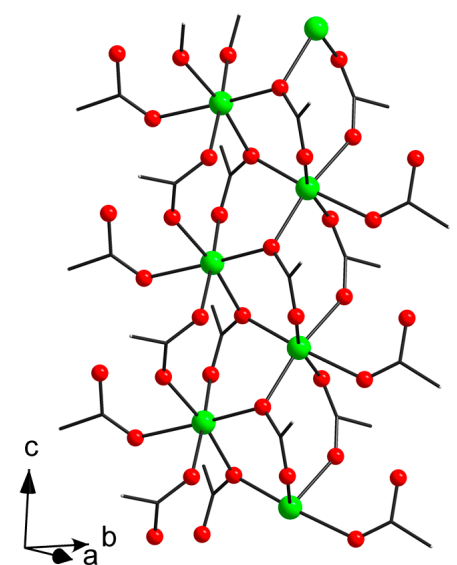

(a)

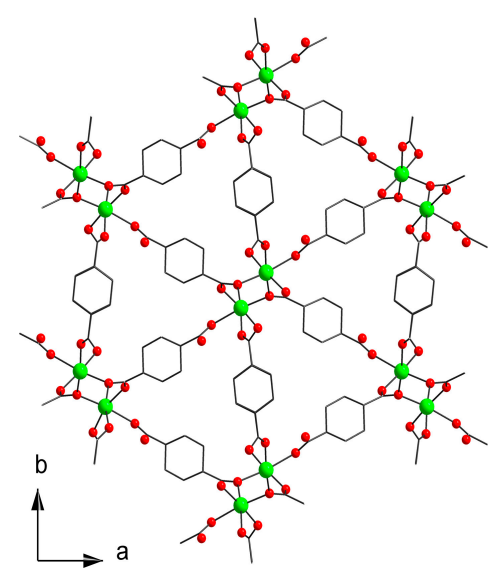

(b)

Figure 4. Fragment of polymeric chain in (a) and metal-organic framework (b) in 5o (CCDC 1973666). Hydrogen atoms are omitted. Only one of possible orientations of $\mathrm{chdc}^{2-}$ ligand is shown.

Infrared spectra of the compounds 1, 3-5 are typical for metal-carboxylate complexes. All spectra contain $\mathrm{O}-\mathrm{H}$ stretching bands in the $3348-3448 \mathrm{~cm}^{-1}$ region, cyclohexane ring $\mathrm{C}\left(\mathrm{sp}^{3}\right)-\mathrm{H}$ stretching bands in the 2856-2957 $\mathrm{cm}^{-1}$ region, COO antisymetric and symmetric stretching bands at 1552-1586 $\mathrm{cm}^{-1}$ and $1406-1422 \mathrm{~cm}^{-1}$, respectively. For 5, the O-H band at $3448 \mathrm{~cm}^{-1}$ is very broad and weak and can be attributed to the presence of protonated $\mathrm{COOH}$ groups.

\subsection{Magnetochemical Analysis}

Temperature dependencies of the effective magnetic moment $\left(\mu_{\text {eff }}\right)$ and inverse magnetic susceptibility for complex 1 are shown in Figure 5. The $\mu_{\text {eff }}$ value is $4.82 \mu_{\mathrm{B}}$ at $300 \mathrm{~K}$ and decreases to $4.69 \mu_{\mathrm{B}}$ at $80 \mathrm{~K}$. The $1 / \chi$ dependence is linear in the temperature range of $80-300 \mathrm{~K}$ and obeys the Curie-Weiss law with the best fit parameters $C=2.99 \mathrm{~K} \mathrm{~cm}^{3} \mathrm{~mol}^{-1}$ and $\theta=-7 \mathrm{~K}$. The values of the $\mu_{\text {eff }}$ at $300 \mathrm{~K}$ and Curie constant $C$ are higher than the theoretical spin only for the values of $3.87 \mu_{\mathrm{B}}$ and $1.875 \mathrm{~K} \cdot \mathrm{cm}^{3} / \mathrm{mol}^{-1}$, respectively, which is typical for the Co(II) ion in the octahedral environment orbital contribution to the magnetic susceptibility [35,36]. Spin-orbit coupling causes decreasing of the $\mu_{\text {eff }}$ with lowering temperature.

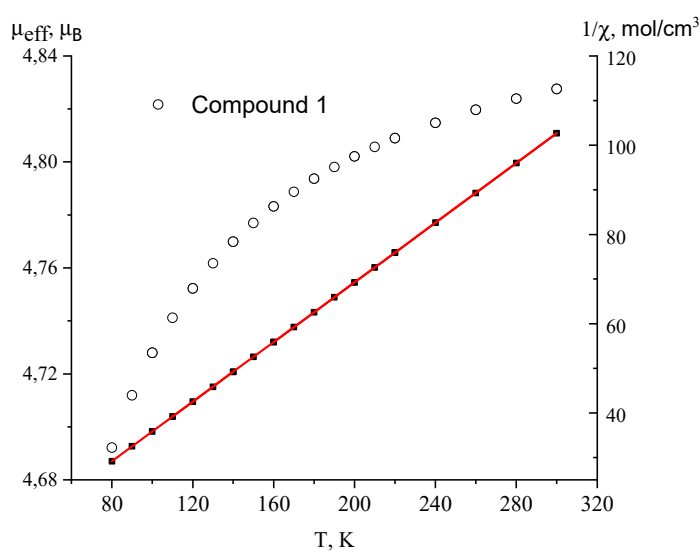

Figure 5. Temperature dependencies of the $\mu_{\text {eff }}(\bigcirc)$ and $1 / \chi(\boldsymbol{\square})$ for complex 1 . Solid line is a theoretical curve.

The $\mu_{\text {eff }}(\mathrm{T})$ and $1 / \chi(\mathrm{T})$ dependencies for 4 and 5 are presented in Figure 6 . The $\mu_{\text {eff }}$ values at $300 \mathrm{~K}$ are $9.23 \mu_{\mathrm{B}}$ and $7.77 \mu_{\mathrm{B}}$ and decrease gradually with lowering temperature down to $1.28 \mu_{\mathrm{B}}$ and $3.4 \mu_{\mathrm{B}}$ 
at $2 \mathrm{~K}$ for complexes 4 and 5, respectively. The $1 / \chi(\mathrm{T})$ dependencies are linear in the temperature range 30-300 K and obey the Curie-Weiss law with optimal values of Curie constant $C$ and Weiss constant $\theta$ equal to $15.25 \mathrm{~K} \cdot \mathrm{cm}^{3} / \mathrm{mol}$ and $-126 \mathrm{~K}$ for 4 and $8.033 \mathrm{~K} \cdot \mathrm{cm}^{3} / \mathrm{mol}$ and $-19.5 \mathrm{~K}$ for 5 . The values of $\mu_{\text {eff }}$ at $300 \mathrm{~K}$ and the Curie constant $C$ are lower than theoretical spin only ones $11.83 \mu_{\mathrm{B}}$ and $17.5 \mathrm{~K} \cdot \mathrm{cm}^{-1} / \mathrm{mol}$ for four noninteracting Mn (II) ions and $8.37 \mu_{\mathrm{B}}$ and $8.75 \mathrm{~K} \cdot \mathrm{cm}^{3} / \mathrm{mol}$ for two noninteracting Mn (II) ions for complexes 4 and 5 , respectively. A decrease of $\mu_{\text {eff }}$ with lowering temperature and negative values of the Weiss constant $\theta$ indicate the presence of antiferromagnetic exchange interactions between the spins of Mn (II) ions. It should be noted that the low $\mu_{\text {eff }}$ value for 4 at $300 \mathrm{~K}\left(9.23 \mu_{\mathrm{B}}\right.$ instead of 11.83 $\mu_{\mathrm{B}}$ theoretical value) indicates that antiferromagnetic coupling is strong even at room temperature. This behavior is reasonable due to the presence of four crystallographically independent Mn(II) ions and several possible ways of magnetic exchange within the polymeric layer with unique decanuclear $\mathrm{Mn}(\mathrm{II})$ rings.

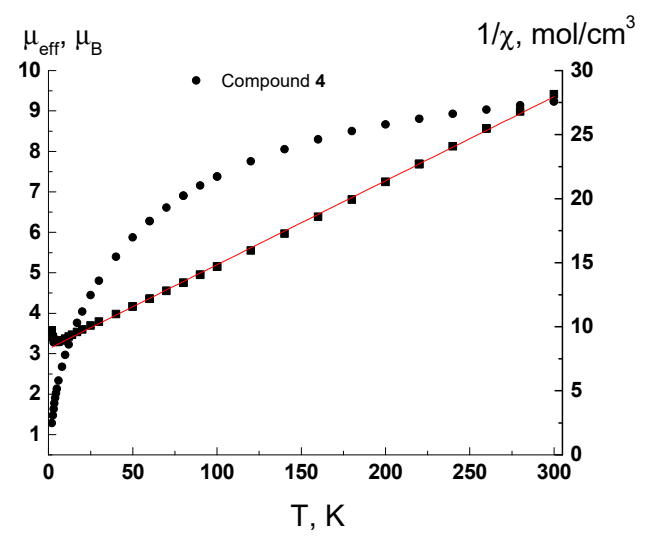

(a)

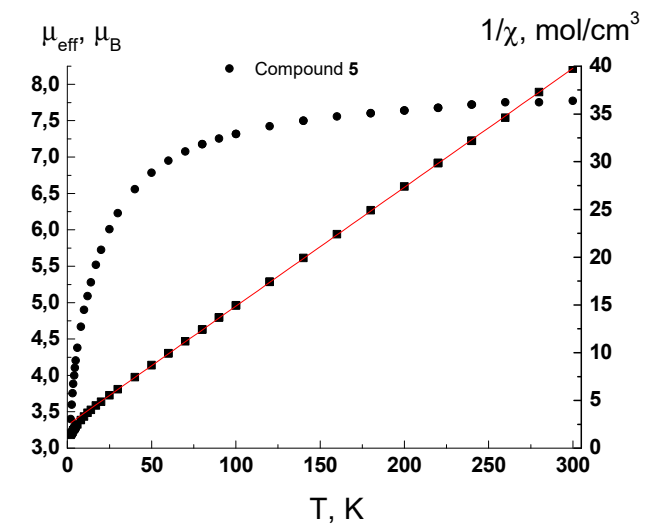

(b)

Figure 6. Temperature dependences of the $\mu_{\mathrm{eff}}(\bullet)$ and $1 / \chi(\boldsymbol{\square})$ for complexes $4(\mathbf{a})$ and $5(\mathbf{b})$. Solid lines are theoretical curves.

\subsection{Thermal Stability and Thermolysis}

Thermogravimetric analyses of the compounds 1, 3-5 were performed under He of Ar flow. Compound 1 shows weight loss ca. $24 \%$ occurring up to $120^{\circ} \mathrm{C}$, assigned to the full loss of coordinated water molecules (Figure S8). The first weight loss is followed by a plateau region ranging up to $460{ }^{\circ} \mathrm{C}$ with further heating leading to decomposition of the framework.

Compound 3 demonstrates weight loss ca. $12 \%$ at $160-180{ }^{\circ} \mathrm{C}$, which corresponds to the loss of coordinated water and $\mathrm{CH}_{3} \mathrm{CN}$ guest molecules (Figure S9). This temperature is much higher than boiling point of acetonitrile $\left(82^{\circ} \mathrm{C}\right)$ and water, despite its coordinated nature. The reason for such pronounced thermal stability is isolated structure of pores (see the structure description in Section 2.2). The first weight loss in followed by a plateau region ranging up to $450^{\circ} \mathrm{C}$. Several attempts were performed to activate samples of 3 by heating at $80-100{ }^{\circ} \mathrm{C}$ in vacuum. It was shown that the crystallinity of activated samples is significantly reduced (Figure S10), and the samples do not show adsorption of $\mathrm{N}_{2}$ at $77 \mathrm{~K}$ and $\mathrm{CO}_{2}$ at $195 \mathrm{~K}$.

Compound 4 demonstrates weight loss ca. $5 \%$ at $180-200{ }^{\circ} \mathrm{C}$ due to the loss of coordinated water molecules (Figure S11), and further decomposition at $530^{\circ} \mathrm{C}$. The thermal properties of 5 (Figure S12) are more complex and reveal multiple intermediate states due to consecutive liberation of organic ligands. The first weight loss at $250-270{ }^{\circ} \mathrm{C}(29 \%)$ leads to $\mathrm{Mn}_{2}(\mathrm{chdc})_{2}$ intermediate (calculated-28\%) apparently due to the escape of the $\mathrm{H}_{2}$ chdc molecule. The second step at $330-340{ }^{\circ} \mathrm{C}(20 \%)$ leads to an unknown phase or a mixture, followed by pyrolysis, completed at $520^{\circ} \mathrm{C}$ with the formation of $\mathrm{MnO}$ ( $21 \%$ of the residual sample mass vs. $23 \%$ in theory). 
Due to the wide applicability of metal oxide nanoparticles and a number of advantages of MOF sources for pyrolysis [37-42], the compounds 1, 4, 5 were considered as the precursors for the synthesis of the corresponding oxides by thermolysis in air. The temperatures of the decomposition were chosen as $600{ }^{\circ} \mathrm{C}$ for all compounds, according to TG data. The thermolysis products were identified as cubic $\mathrm{Co}_{3} \mathrm{O}_{4}$ for 1 (Figure S13) and cubic MnO for $\mathbf{4} \mathbf{- 5}$ according to PXRD (Figure S14). The coherence scattering areas of crystalline oxide nanoparticles were estimated by the Scherrer equation. The corresponding numbers are 53.6(5) $\mathrm{nm}$ for $\mathrm{Co}_{3} \mathrm{O}_{4}$ derived from 1, 43.5(4) $\mathrm{nm}$ for $\mathrm{MnO}$ derived from 4 and 55.7(9) $\mathrm{nm}$ for $\mathrm{MnO}$ derived from 5. While the coherence scattering areas of $\mathrm{MnO}$ nanocrystallites obtained from 4 or 5 are quite similar, the macroscopic shape of the metal oxide aggregates is markedly different from each other. As revealed by scanning electron microscopy (SEM), the morphology of $\mathrm{MnO}$ aggregates is similar to that of the initial MOF crystals: rhomboidal blocks for 4 and sticks for 5, respectively (Figure 7). Such a morphological "memory effect" is not uncommon and could provide a convenient way for the control of the texture of the oxide phase on a macroscopic level, which, in turn, will affect certain functional properties of the bulk material, such as particle density, surface area, catalytic activity, and chemical reactivity.

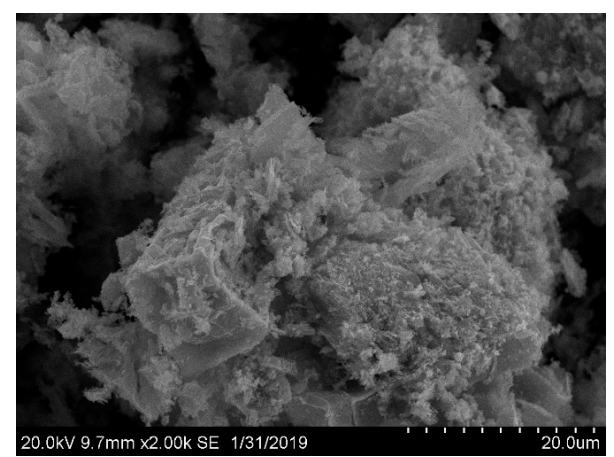

(a)

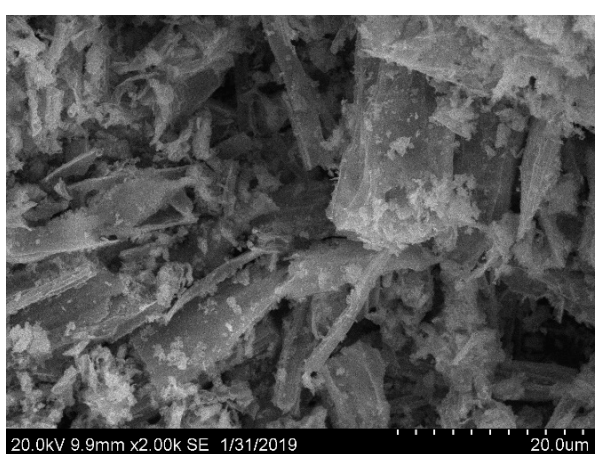

(b)

Figure 7. SEM images of MnO sample obtained by the oxidative thermolysis of 4 (a) and 5 (b).

\section{Conclusions}

To summarize, five new metal-organic frameworks (MOFs) based on trans-1,4-cyclohexanedicarboxylate linker were synthesized and characterized by elemental analysis, IR spectroscopy, powder diffraction and X-ray single crystal analysis. Fine optimization of the reaction conditions, including the solvent composition, temperature and reaction mixture $\mathrm{pH}$, was found to be crucial to achieve a phase pure product with high crystallinity.

Isostructural $\left[\mathrm{Co}\left(\mathrm{H}_{2} \mathrm{O}\right)_{4}(\mathrm{chdc})\right]_{n}(\mathbf{1})$ and $\left[\mathrm{Fe}\left(\mathrm{H}_{2} \mathrm{O}\right)_{4}(\mathrm{chdc})\right]_{\mathrm{n}}$ (2) consist of one-dimensional hydrogen-bonded chains. Compounds $\left[\mathrm{Cd}\left(\mathrm{H}_{2} \mathrm{O}\right)(\mathrm{chdc})\right]_{\mathrm{n}} \cdot 0.5 \mathrm{nCH}_{3} \mathrm{CN}(3),\left[\mathrm{Mn}_{4}\left(\mathrm{H}_{2} \mathrm{O}\right)_{3}(\mathrm{chdc})_{4}\right]_{\mathrm{n}}$ (4) and $\left[\mathrm{Mn}_{2}(\mathrm{Hchdc})_{2}(\mathrm{chdc})\right]_{\mathrm{n}}(5)$ possess three-dimensional framework structures.

Metal-organic frameworks with paramagnetic metal cations $\mathrm{Co}(\mathrm{II}), \mathrm{Mn}(\mathrm{II})$ were studied by magnetochemical and thermal analyses. For the compound $\left[\mathrm{Co}\left(\mathrm{H}_{2} \mathrm{O}\right)_{4}(\mathrm{chdc})\right]_{\mathrm{n}}(\mathbf{1})$ with chain-like structure, a typical decrease of the magnetic moment $\mu_{\text {eff }}$ was observed with lowering temperature due to a spin-orbit coupling. For the metal-organic frameworks with $\mathrm{Mn}(\mathrm{II})$, a presence of antiferromagnetic exchange was revealed, which is especially strong in $\left[\mathrm{Mn}_{4}\left(\mathrm{H}_{2} \mathrm{O}\right)_{3}(\mathrm{chdc})_{4}\right]_{\mathrm{n}}(4)$ even at room temperature due to different possible ways of magnetic exchange within the polymeric layer with unique decanuclear $\mathrm{Mn}(\mathrm{II})$ rings.

The thermolysis of the compounds based on $\mathrm{Co}(\mathrm{II})$ and $\mathrm{Mn}(\mathrm{II})$ in oxygen-containing atmosphere produces macroscopic aggregates made of nanosized oxide phases of cubic $\mathrm{Co}_{3} \mathrm{O}_{4}$ and $\mathrm{MnO}$, respectively. These aggregates inherit the shape of the crystals of the initial MOFs, making possible a control of functional properties of the bulk material by varying the MOF precursor. 
Supplementary Materials: The following are available online at http://www.mdpi.com/1996-1944/13/2/486/s1, Figure S1: PXRD pattern of the synthesized sample of $\mathbf{1}$ (black) in comparison with the theoretical one (red), Figure S2: PXRD pattern of the synthesized sample of 3 (black) in comparison with the theoretical one (red), Figure S3: PXRD pattern of the synthesized sample of 4 (black) in comparison with the theoretical one (red), Figure S4: PXRD pattern of the synthesized sample of 5 (black) in comparison with the theoretical one (red), Figure S5: Location of guest $\mathrm{CH}_{3} \mathrm{CN}$ molecules in the cage of 3, Figure S6: Interconnection between AB layers into 3D framework in 4, Figure S7: The schematic illustration of AB-packing in 4, Figure S8: TG plot for the compound 1, Figure S9: TG plot for the compound 3, Figure S10: PXRD pattern of the activated sample of 3 (black) in comparison with the theoretical for 3 (red), Figure S11: TG plot for the compound 4, Figure S12: TG plot for the compound 5, Figure S13: PXRD pattern of the $\mathrm{Co}_{3} \mathrm{O}_{4}$ sample derived from 1 by the oxidative thermolysis, Figure S14: PXRD patterns of the $\mathrm{MnO}$ samples derived from 4 (red) and 5 (black) by the oxidative thermolysis, Figure S15: SEM image of $\mathrm{Co}_{3} \mathrm{O}_{4}$ sample obtained by the oxidative thermolysis of $\mathbf{1}$.

Author Contributions: D.N.D. and V.P.F. conceptualized and supervised. P.A.D. prepared the original manuscript. P.A.D., A.S.B., A.S.U., A.Y.A. and D.G.S. performed experimental work. V.P.F. acquired the funding. P.A.D., A.S.B., A.Y.A., D.G.S., D.N.D. and V.P.F. contributed to writing, editing and analysis. All the authors equally contributed in this manuscript. All authors have read and agreed to the published version of the manuscript.

Funding: This research was financially supported by the Russian Foundation for Basic Research, Project Number 18-29-04001.

Conflicts of Interest: The authors declare no conflict of interest.

\section{Appendix A. New Polymorph of (e,e)- $\mathrm{H}_{2}$ chdc}

The single crystals of trans- $\mathrm{H}_{2}$ chdc (6) were obtained in all synthetic schemes, which were similar to the $1-5$ methods, but carried out without the addition of the organic base (DABCO or urotropine). Moreover, similar crystals of 6 were obtained at recrystallization of $\mathrm{H}_{2}$ chdc from water. This structure has not been reported early and is different to the known monoclinic crystal structure of trans- $\mathrm{H}_{2}$ chdc [43]. Compound 6 crystallizes in the triclinic symmetry with $P-1$ space group. $\mathrm{C}_{\mathrm{COO}}-\mathrm{O}_{\mathrm{COO}}$ distances are 1.2205(1) $\AA$ and 1.3195(2) $\AA$. C-C bond lengths in the cyclohexane ring are in the range of 1.5261(3)-1.5348(3) $\mathrm{H}_{2}$ chdc molecules adopt biequatroial (e,e) conformation. The $\mathrm{COOH}$ groups of neighboring $\mathrm{H}_{2}$ chdc molecules contact with the formation of $\mathrm{H}$-bonds in a typical for carboxylic acids manner resulting in the formation of parallel one-dimensional $\mathrm{H}$-bonded chains that are packed along each other in AA manner to form a 3D dense structure. The reported earlier structure of trans- $\mathrm{H}_{2}$ chdc adopts AB-packing. The rotation angle of carboxylic groups relative to the cyclohexane ring plane is also different in these to structures $\sim 45^{\circ}$ for 6 and $\sim 15^{\circ}$ for the previously reported trans $-\mathrm{H}_{2}$ chdc phase.

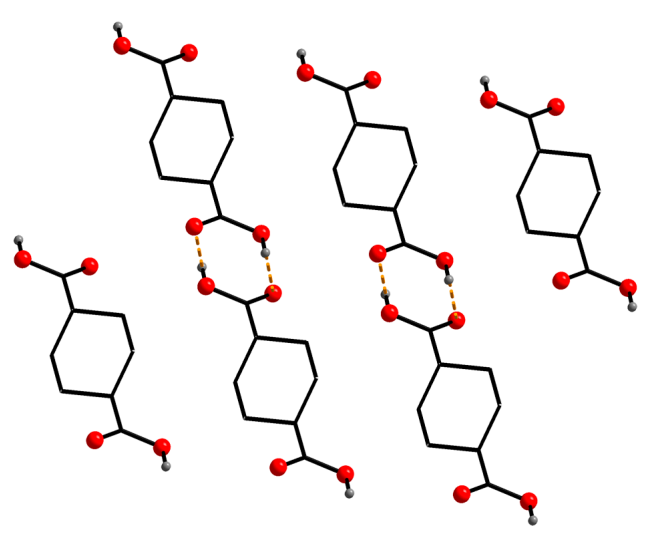

(a)

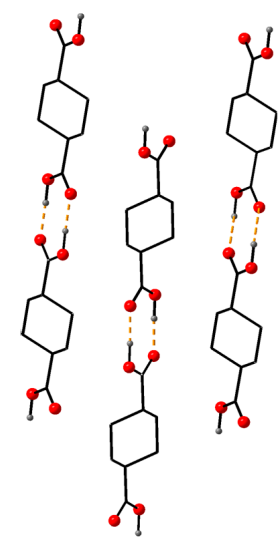

(b)

Figure A1. Packing of $\mathrm{H}_{2}$ chdc molecules in 6 (CCDC 1973668) (a) and the previously reported $\mathrm{H}_{2}$ chdc (b). Hydrogen bonds are shown in orange. 


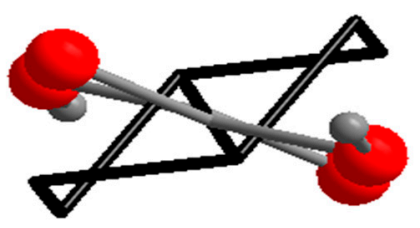

(a)

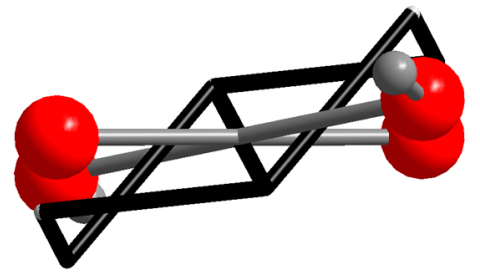

(b)

Figure A2. Conformations of $\mathrm{H}_{2}$ chdc molecule in $\mathbf{6}$ (a) and in previously reported polymorph (b).

The crystal structure of the less stable $(\mathrm{a}, \mathrm{a})$ conformer is not reported in literature. There is a reported SCXRD data to cis-isomer- $(\mathrm{e}, \mathrm{a})-\mathrm{H}_{2}$ chdc [44], which cannot pass to (e,e)- $\mathrm{H}_{2}$ chdc by a conformational transition. 


\section{Appendix B. Crystallographic Data}

Table A1. Crystallographic data for 1-6

\begin{tabular}{|c|c|c|c|c|c|c|c|}
\hline Compound Number & 1 & 2 & 3 & 4 & 50 & $5 \mathrm{~m}$ & 6 \\
\hline $\begin{array}{c}\text { Chemical formula } \\
M_{\mathrm{r}} \mathrm{g} \cdot \mathrm{mol}^{-1}\end{array}$ & $\begin{array}{c}\mathrm{C}_{8} \mathrm{H}_{18} \mathrm{CoO}_{8} \\
301.15\end{array}$ & $\begin{array}{c}\mathrm{C}_{8} \mathrm{H}_{18} \mathrm{FeO}_{8} \\
298.07\end{array}$ & $\begin{array}{c}\mathrm{C}_{9} \mathrm{H}_{13.5} \mathrm{CdN}_{0.5} \mathrm{O}_{5} \\
321.10\end{array}$ & $\begin{array}{c}\mathrm{C}_{32} \mathrm{H}_{46} \mathrm{Mn}_{4} \mathrm{O}_{19} \\
954.45\end{array}$ & $\begin{array}{c}\mathrm{C}_{24} \mathrm{H}_{32} \mathrm{Mn}_{2} \mathrm{O}_{12} \\
622.37\end{array}$ & $\begin{array}{c}\mathrm{C}_{24} \mathrm{H}_{32} \mathrm{Mnn}_{2} \mathrm{O}_{12} \\
622.37\end{array}$ & $\begin{array}{c}\mathrm{C}_{8} \mathrm{H}_{12} \mathrm{O}_{4} \\
172.18\end{array}$ \\
\hline $\begin{array}{l}\text { Crystal system, } \\
\text { space group }\end{array}$ & $\begin{array}{c}\text { Triclinic, } \\
P^{-1}\end{array}$ & $\begin{array}{c}\text { Triclinic, } \\
P^{-} 1\end{array}$ & $\begin{array}{c}\text { Monoclinic, } \\
P 2_{1} / c\end{array}$ & $\begin{array}{c}\text { Monoclinic, } \\
2_{1} / c\end{array}$ & $\begin{array}{l}\text { Orthorhombic, } \\
\text { Fdd2 }\end{array}$ & $\begin{array}{l}\text { Monoclinic, } \\
\mathrm{P} 2_{1}\end{array}$ & $\begin{array}{c}\text { Triclinic, } \\
P^{-} 1\end{array}$ \\
\hline Temperature (K) & 130 & 130 & 130 & 130 & 130 & 130 & 130 \\
\hline$a, b, c(\AA)$ & $\begin{array}{l}4.9320(4), \\
6.3130(5), \\
9.5216(7)\end{array}$ & $\begin{array}{c}4.9361(4) \\
6.3194(6), 9.5296(9)\end{array}$ & $\begin{array}{c}10.6697(5), \\
22.4618(11) \\
9.6558(5)\end{array}$ & $\begin{array}{l}10.9672(2), \\
16.7768(3) \\
19.6763(4)\end{array}$ & $\begin{array}{c}42.792(3), \\
23.7832(12), \\
4.8132(2)\end{array}$ & $\begin{array}{l}23.7915(19), \\
4.81470(19), \\
24.4802(18)\end{array}$ & $\begin{array}{c}5.2936(7) \\
5.6436(8) \\
7.2022(12)\end{array}$ \\
\hline$\alpha, \beta, \gamma\left(^{\circ}\right)$ & $\begin{array}{l}80.347(6) \\
79.008(6), \\
77.250(7)\end{array}$ & $\begin{array}{l}\text { 80.655(8), } \\
79.183(8), \\
77.743(8)\end{array}$ & $\begin{array}{c}90.0000 \\
113.017(6) \\
90.0000\end{array}$ & $\begin{array}{c}90.0000 \\
90.2332(18) \\
90.0000\end{array}$ & $\begin{array}{l}90.0000 \\
90.0000 \\
90.0000\end{array}$ & $\begin{array}{c}90.0000 \\
119.049(10) \\
90.0000\end{array}$ & $\begin{array}{l}71.861(14), \\
78.609(13) \\
79.854(12)\end{array}$ \\
\hline$V\left(\AA^{3}\right)$ & $281.39(4)$ & $282.99(5)$ & $2129.9(2)$ & $3620.29(13)$ & $4898.5(5)$ & $2451.4(4)$ & 198.92(5) \\
\hline Z & 1 & 1 & 8 & 4 & 8 & 4 & 1 \\
\hline$\mu\left(\mathrm{mm}^{-1}\right)$ & 1.55 & 1.36 & 2.05 & 1.45 & 1.10 & 1.10 & 0.12 \\
\hline & $0.50 \times$ & $0.23 \times$ & $0.58 \times$ & $0.55 \times$ & $0.29 \times$ & $0.29 \times$ & $0.13 \times$ \\
\hline Crystal size (mm) & $\begin{array}{c}0.31 \times \\
0.15\end{array}$ & $\begin{array}{c}0.07 \times \\
0.07\end{array}$ & $\begin{array}{c}0.47 \times \\
0.16\end{array}$ & $\begin{array}{c}0.30 \times \\
0.22\end{array}$ & $\begin{array}{c}0.05 \times \\
0.05\end{array}$ & $\begin{array}{c}0.05 \times \\
0.05\end{array}$ & $\begin{array}{c}0.08 \times \\
0.07\end{array}$ \\
\hline $\begin{array}{c}\text { No. of measured, } \\
\text { independent } \\
\text { and observed } \\
{[I>2 \sigma(I)] \text { reflections }}\end{array}$ & $\begin{array}{l}4449 \\
1382, \\
1351\end{array}$ & $\begin{array}{l}2138 \\
1302, \\
1220\end{array}$ & $\begin{array}{c}10553 \\
4912, \\
4554\end{array}$ & $\begin{array}{l}30543, \\
8653, \\
7694\end{array}$ & $\begin{array}{l}5975, \\
2077 \\
1837\end{array}$ & $\begin{array}{l}12172 \\
7973 \\
5190\end{array}$ & $\begin{array}{l}1493 \\
918 \\
722\end{array}$ \\
\hline$R_{\text {int }}$ & 0.026 & 0.020 & 0.017 & 0.024 & 0.044 & 0.045 & 0.013 \\
\hline$R\left[F^{2}>2 \sigma\left(F^{2}\right)\right]$ & 0.021 & 0.026 & 0.022 & 0.030 & 0.037 & 0.059 & 0.040 \\
\hline$w R\left(F^{2}\right)$ & 0.057, & 0.061, & 0.048 & 0.069 & 0.074 & 0.105 & 0.089, \\
\hline$S$ & 1.13 & 1.05 & 1.11 & 1.02 & 1.04 & 0.98 & 1.03 \\
\hline No. of parameters & 91 & 91 & 293 & 533 & 220 & 698 & 57 \\
\hline No. of restraints & 4 & 4 & 5 & 69 & 103 & 453 & 0 \\
\hline $\begin{array}{c}\Delta \rho_{\max }, \Delta \rho_{\min } \\
\left(\mathrm{e} \cdot \AA^{-3}\right)\end{array}$ & $0.36,-0.47$ & $0.39,-0.30$ & $0.63,-0.63$ & $1.23,-1.26$ & $0.44,-0.36$ & $0.49,-0.57$ & $0.28,-0.20$ \\
\hline
\end{tabular}




\section{References}

1. Zhou, H.C.; Long, J.R.; Yaghi, O.M. Introduction to Metal-Organic Frameworks. Chem. Rev. 2012, 112, 673-674. [CrossRef] [PubMed]

2. Howarth, A.J.; Peters, A.W.; Vermeulen, N.A.; Wang, T.C.; Hupp, J.T.; Farha, O.K. Best practices for the synthesis, activation, and characterization of metal-organic frameworks. Chem. Mater. 2017, 29, $26-39$. [CrossRef]

3. Pascanu, V.; González Miera, G.; Ken Inge, A.; Martín-Matute, B. Metal-Organic Frameworks as Catalysts for Organic Synthesis: A Critical Perspective. J. Am. Chem. Soc. 2019, 141, 7223-7234. [CrossRef] [PubMed]

4. Han, Z.; Shi, W.; Cheng, P. Synthetic strategies for chiral metal-organic frameworks. Chin. Chem. Lett. 2017, 29, 819-822. [CrossRef]

5. Sun, D.; Han, L.-L.; Yuan, S.; Deng, Y.-K.; Xu, M.-Z.; Sun, D.-F. Four New Cd(II) Coordination Polymers with Mixed Multidentate N-Donors and Biphenyl-Based Polycarboxylate Ligands: Syntheses, Structures, and Photoluminescent Properties. Cryst. Growth Des. 2013, 13, 377-385. [CrossRef]

6. Kim, Y.J.; Jung, D.Y. Conformation change of the cyclohexanedicarboxylate ligand toward 2D and 3D La(iii)-organic coordination networks. Chem. Commun. 2002, 8, 908-909.

7. Chen, J.; Ohba, M.; Zhao, D.; Kaneko, W.; Kitagawa, S. Polynuclear core-based nickel 1,4-cyclohexanedicarboxylate coordination polymers as temperature-dependent hydrothermal reaction products. Cryst. Growth Des. 2006, 6, 664-668. [CrossRef]

8. Chi-Duran, I.; Enríquez, J.; Manquian, C.; Wrighton-Araneda, K.; Cañon-Mancisidor, W.; Venegas-Yazigi, D.; Herrera, F.; Pratap Singh, D. pH-Controlled Assembly of 3D and 2D Zinc-Based Metal-Organic Frameworks with Tetrazole Ligands. ACS Omega 2018, 3, 801-807. [CrossRef]

9. Kim, Y.J.; Jung, D.Y. Hydrothermal Synthesis and Magnetic Behavior of a Novel Layered Coordination Polymer Generated from Manganese (II) Adipate. Inorg. Chem. 2000, 39, 1470-1475. [CrossRef]

10. Zhou, G.J.; Richter, J.; Schnack, J.; Zheng, Y.Z. Hydrophobicity-Driven Self-Assembly of an Eighteen-Membered Honeycomb Lattice with Almost Classical Spins. Chem. Eur. J. 2016, 22, 14846-14850. [CrossRef]

11. Martínez Casado, F.J.; Fabelo, O.; Rodríguez-Velamazan, J.A.; Ramos Riesco, M.; Rodríguez Cheda, J.A.; Labrador, A.; Rodríguez-Blanco, C.; Campo, J.; Sanchez-Alarcos, V.; Muller, H. Manganese(II) Butyrate-Based MOFs: Structures, Thermal and Magnetic Properties. Cryst. Growth Des. 2011, 11, 4080-4089. [CrossRef]

12. Reinsch, H.; De Vos, D. Structures and properties of gallium-MOFs with MIL-53-topology based on aliphatic linker molecules. Microporous Mesoporous Mater. 2014, 200, 311-316. [CrossRef]

13. Reinsch, H.; Pillai, R.S.; Siegel, R.; Senker, J.; Lieb, A.; Maurin, G.; Stock, N. Structure and properties of Al-MIL-53-ADP, a breathing MOF based on the aliphatic linker molecule adipic acid. Dalton Trans. 2016, 45, 4179-4186. [CrossRef]

14. Bueken, B.; Vermoortele, F.; Vanpoucke, D.E.P.; Reinsch, H.; Tsou, C.-C.; Valvekens, P.; De Baerdemaeker, T.; Ameloot, R.; Kirschhock, C.E.A.; Van Speybroeck, V.; et al. A Flexible Photoactive Titanium Metal-Organic Framework Based on a [Ti $\left.{ }^{\mathrm{IV}} 3(\mu 3-\mathrm{O})(\mathrm{O}) 2(\mathrm{COO}) 6\right]$ Cluster. Angew. Chem. Int. Ed. 2015, 54, 13912-13917. [CrossRef] [PubMed]

15. Niekiel, F.; Lannoeye, J.; Reinsch, H.; Munn, A.S.; Heerwig, A.; Zizak, I.; Kaskel, S.; Walton, R.I.; De Vos, D.; Llewellyn, P.; et al. Conformation-controlled sorption properties and breathing of the aliphatic Al-MOF [Al(OH)(CDC)]. Inorg. Chem. 2014, 53, 4610-4620. [CrossRef] [PubMed]

16. Bueken, B.; Vermoortele, F.; Cliffe, M.J.; Wharmby, M.T.; Foucher, D.; Wieme, J.; Vanduyfhuys, L.; Martineau, C.; Stock, N.; Taulelle, F.; et al. A Breathing Zirconium Metal-Organic Framework with Reversible Loss of Crystallinity by Correlated Nanodomain Formation. Chem. Eur. J. 2016, 22, 3264-3267. [CrossRef]

17. Bueken, B.; Van Velthoven, N.; Krajnc, A.; Smolders, S.; Taulelle, F.; Mellot-Draznieks, C.; Mali, G.; Bennett, T.D.; De Vos, D. Tackling the Defect Conundrum in UiO-66: A Mixed-Linker Approach to Engineering Missing Linker Defects. Chem. Mater. 2017, 29, 10478-10486. [CrossRef]

18. Kim, T.K.; Lee, K.J.; Cheon, J.Y.; Lee, J.H.; Joo, S.H.; Moon, H.R. Nanoporous Metal Oxides with Tunable and Nanocrystalline Frameworks via Conversion of Metal-Organic Frameworks. J. Am. Chem. Soc. 2013, 135, 8940-8946. [CrossRef] 
19. Lim, S.; Suh, K.; Kim, Y.; Yoon, M.; Park, H.; Dybtsev, D.N.; Kim, K. Porous carbon materials with a controllable surface area synthesized from metal-organic frameworks. Chem. Commun. 2012, 48, 7447-7449. [CrossRef]

20. Xi, K.; Cao, S.; Peng, X.; Ducati, C.; Kumar, V.; Cheetham, A.K. Carbon with hierarchical pores from carbonized metal-organic frameworks for lithium sulphur batteries. Chem. Commun. 2013, 49, 2192-2194. [CrossRef]

21. Kurmoo, M.; Kumagai, H.; Hughes, S.M.; Kepert, C.J. Reversible guest exchange and ferrimagnetism $(\mathrm{T}(\mathrm{C})=$ $60.5 \mathrm{~K})$ in a porous cobalt(II)-hydroxide layer structure pillared with trans-1,4-cyclohexanedicarboxylate. Inorg. Chem. 2003, 42, 6709-6722. [CrossRef] [PubMed]

22. Yoon, M.; Sun, H.J.; Lee, D.H.; Park, G. Synthesis and Structure of a 3-D Metal-Organic Framework, $\left[\mathrm{Cd}_{2} \text { (1,4-cyclohexanedicarboxylate) }\right)_{2}$ DMF], Comprising Unusual Two Different Ligand Conformations. Bull. Korean Chem. Soc. 2012, 33, 3111-3114. [CrossRef]

23. Thirumurugan, A.; Avinash, M.B.; Rao, C.N.R. 1, 2-, 1, 3- and 1, 4-Cyclohexanedicarboxylates of Cd and Mn with chain and layered structures. Dalton Trans. 2006, 221-228. [CrossRef] [PubMed]

24. Zheng, Y.Z.; Xue, W.; Zhang, W.X.; Tong, M.L.; Chen, X.M.; Grandjean, F.; Long, G.J.; Ng, S.W.; Panissod, P.; Drillon, M. Spin-Frustrated Complex, [FeIIFeIII(trans-1,4-cyclohexanedicarboxylate)1.5] $\infty$ : Interplay between Single-Chain Magnetic Behavior and Magnetic Ordering. Inorg. Chem. 2009, 48, 2028-2042. [CrossRef]

25. Demakov, P.A.; Sapchenko, S.A.; Samsonenko, D.G.; Dybtsev, D.N.; Fedin, V.P. Coordination polymers based on zinc(II) and manganese(II) with 1,4-cyclohexanedicarboxylic acid. Russ. Chem. Bull. 2018, 67, 490-496. [CrossRef]

26. Rigaku Oxford Diffraction. CrysAlisPro 1.171.38.46; Rigaku Oxford Diffraction: The Woodlands, TX, USA, 2015.

27. Sheldrick, G.M. SHELXT-Integrated space-group and crystal-structure determination. Acta Crystallogr. 2015, A71, 3. [CrossRef]

28. Sheldrick, G.M. Crystal structure refinement with SHELXL. Acta Crystallogr. 2015, C71, 3.

29. Kurmoo, M.; Kumagai, H.; Akita-Tanaka, M.; Inoue, K.; Takagi, S. Metal-organic frameworks from homometallic chains of nickel(II) and 1,4-cyclohexanedicarboxylate connectors: Ferrimagnet-ferromagnet transformation. Inorg. Chem. 2006, 45, 1627-1637. [CrossRef]

30. Koutentis, P.A.; Koyioni, M.; Michaelidou, S.S. Synthesis of [(4-Chloro-5H-1,2,3-dithiazol-5-ylidene)amino]azines. Molecules 2011, 16, 8992-9002. [CrossRef]

31. Li, Z.Y.; Cao, Y.Q.; Zhang, X.M.; Xu, Y.L.; Cao, G.X.; Zhang, F.L.; Li, S.Z.; Zhanga, F.Q.; Zhai, B. Linking cobalt-water chains with cis-1,4-cyclohexanedicarboxylate bridges to form a 2D network exhibiting spin-canted antiferromagnetism. New J. Chem. 2017, 41, 457-461. [CrossRef]

32. Spek, A.L. Single-crystal structure validation with the program PLATON. J. Appl. Crystallogr. 2003, 36, 7-13. [CrossRef]

33. Liu, S.; Jeppson, P.; Sandstrom, J.; Caruso, A.N.; Schulz, D.L. Synthesis, structure and magnetic properties of $\{\mathrm{Mn} 5(\mathrm{OC}(\mathrm{O}) \mathrm{CH} 3) 6(\mathrm{OC}(\mathrm{O}) \mathrm{C} 6 \mathrm{H} 5) 4\} \infty$. Polyhedron 2007, 26, 2235-2242. [CrossRef]

34. Liu, S.; Bremer, M.T.; Lovaasen, J.; Caruso, A.N.; O’Neill, K.; Simpson, L.; Parilla, P.A.; Heben, M.J.; Schulz, D.L. Structural and magnetic studies of two-dimensional solvent-free manganese ${ }^{\mathrm{II}}$ complexes prepared via ligand exchange reaction under solvothermal conditions. Inorg. Chem. 2008, 47, 1568-1575. [CrossRef]

35. Bushuev, M.B.; Virovets, A.V.; Garcia, Y.; Gieck, C.; Sheludyakova, L.A.; Ikorskii, V.N.; Tremel, W.; Gütlich, P.; Lavrenova, L.G. Mononuclear coordination compounds based on a novel chelating triazole ligand: 1-vinyl-3-acetylamino-1,2,4-triazole. Polyhedron 2002, 21, 797-804. [CrossRef]

36. Lavrenova, L.G.; Bushuev, M.B.; Virovets, A.V.; Naumov, D.Y.; Sheludyakova, L.A.; Shvedenkov, Y.G. Coordination Compounds-Synthesis and Study of Cobalt(II), Nickel(II), and Copper(II) Nitrate Complexes with 3-Acetylamino-1,2,4-triazole. Russ. J. Inorg. Chem. 2000, 45, 1658-1663.

37. Peng, L.; Zhang, J.; Xue, Z.; Han, B.; Li, J.; Yang, G. Large-pore mesoporous $\mathrm{Mn}_{3} \mathrm{O}_{4}$ crystals derived from metal-organic frameworks. Chem. Commun. 2013, 49, 11695-11697. [CrossRef] [PubMed]

38. Liu, Q.; Low, Z.-X.; Feng, Y.; Leong, S.; Zhong, Z.; Yao, J.; Hapgood, K.; Wang, H. Direct conversion of two-dimensional ZIF-L film to porous $\mathrm{ZnO}$ nano-sheet film and its performance as photoanode in dye-sensitized solar cell. Microporous Mesoporous Mater. 2014, 194, 1-7. [CrossRef] 
39. Wu, R.; Qian, X.; Rui, X.; Liu, H.; Yadian, B.; Zhou, K.; Wei, J.; Yan, Q.; Feng, X.-Q.; Long, Y.; et al. Zeolitic Imidazolate Framework 67-Derived High Symmetric Porous $\mathrm{Co}_{3} \mathrm{O}_{4}$ Hollow Dodecahedra with Highly Enhanced Lithium Storage Capability. Small 2014, 10, 1932-1938. [CrossRef]

40. Gan, X.; Zheng, R.; Liu, T.; Meng, J.; Chen, R.; Sun, X.; Sun, X. N-Doped Mesoporous $\operatorname{In}_{2} \mathrm{O}_{3}$ for Photocatalytic Oxygen Evolution from the In-based Metal-Organic Frameworks. Chem. Eur. J. 2017, 23, 7264-7271. [CrossRef]

41. Xiao, J.; Diao, K.; Zheng, Z.; Cui, X. MOF-derived porous $\mathrm{ZnO} / \mathrm{Co}_{3} \mathrm{O}_{4}$ nanocomposites for high performance acetone gas sensing. J. Mater. Sci. Mater. Electron. 2018, 29, 8535-8546. [CrossRef]

42. Dong, X.; Su, Y.; Lu, T.; Zhang, L.; Wu, L.; Lv, Y. MOFs-derived dodecahedra porous $\mathrm{Co}_{3} \mathrm{O}_{4}$ : An efficient cataluminescence sensing material for $\mathrm{H}_{2}$ S. Sens. Actuators B 2018, 258, 349-357. [CrossRef]

43. Dunitz, J.D.; Strickler, P. Die Kristallstruktur von 1,4-trans-Cyclohexan-dicarbonsäure. Helv. Chim. Acta 1966, 49, 2505-2515. [CrossRef]

44. Wang, Y.Q.; Weng, J.B. Cis-Cyclohexane-1,4-dicarboxylic acid. Acta Crystallogr. 2009, E65, o1293. [CrossRef] [PubMed]

(C) 2020 by the authors. Licensee MDPI, Basel, Switzerland. This article is an open access article distributed under the terms and conditions of the Creative Commons Attribution (CC BY) license (http://creativecommons.org/licenses/by/4.0/). 